DOI: https://doi.org/10.24144/2409-6857.2019.2(54).122-128

УДК 657

\title{
Йолтуховська О.Ю.
}

\section{ЛЮДСЬКИЙ КАПІТАЛ В КОНТЕКСТІ СТРАТЕГІЧНОГО ВИМІРЮВАННЯ БІЗНЕСУ}

\begin{abstract}
У статті розглядаються теоретико-методичні питання застосування системи збалансованих показників діяльності суб'єктів господарювання як одного із інструментів управління бізнесом у довгостроковій перспективі. В ході дослідження було сформовано методику аналітичного забезпечення відтворення людського капіталу в контексті використання системи збалансованих показників (BSC). Розроблена стратегічна карта, представлена в статті, враховує вплив трудових ресурсів на кінцевий результат діяльності бізнес-одиниць.
\end{abstract}

Ключові слова: система збалансованих показників (BSC), людський капітал, трудові ресурси, стратегічні карти.

Постановка проблеми. Вітчизняні умови господарювання, які характеризуються нестабільним бізнес-середовищем, підвищеним рівнем конкурентної боротьби, відсутністю сталого розвитку, мінливим законодавством, коли вектор економічного розвитку України спрямований на європейську інтеграцію, перегляду вимагають діючі інструменти управління бізнес процесами. Сучасні управлінці, при формування стратегії розвитку суб'єкта господарювання, все частіше почали використовувати взаємопов'язані фінансові та нефінансові показники діяльності підприємства. Закордонні підприємства у свойй практиці використовують збалансовану систему показників (BSC) як ефективний інструмент управління бізнес-одиницями у довгостроковій перспективі. Однак, дана система, яка зарекомендувала себе в іноземних компаніях, вимагає організаційно-методичної модифікації до умов розвитку вітчизняного бізнесу.

Аналіз останніх досліджень та публікацій. Дослідження щодо стратегічного вимірювання бізнесу з використанням системи збалансованих показників, знайшли своє відображення в працях таких провідних науковців, як: Р. Каплан, Д. Нортон, П. Нівен, Л. Пан, О. Лаговська, Р. Ларіна, М. Макаренко, Т. Логутова та інших вчених. Дослідники зробили вагомий внесок у розробку теоретико-практичних засад управління суб'єктом господарювання. Проте, деякі питання залишаються недостатньо розкритими та потребують подальшого дослідження.

Формулювання цілей статті. Основна мета дослідження сфокусована на визначенні напрямів

() Йолтуховська О.Ю., к.е.н., доцент кафедри обліку i аудиту, ДВНЗ «Ужгородський національний університет»; тел.: (050)6667522; e-mail:oksana.yoltukhovska@uzhnu.edu.ua підвищення ринкової вартості підприємства за показником людського капіталу в контексті стратегічного вимірювання бізнесу.

Опис основного матеріалу дослідження. Розвиток систем вимірювання ефективності господарювання до 1980 р. характеризується застосуванням виключно фінансових показників (мультиплікативна модель Дюпона, підхід до визначення рентабельності інвестицій тощо). Зазначимо, що для прийняття управлінських рішень стосовно вибору стратегії розвитку підприємства, здійснення аналізу впровадження та оцінки ефективності реалізації стратегії використання лише фінансових (монетарних) показників господарювання, не дозволяє врахувати цілий ряд параметрів впливу на діяльність. Це в свою чергу призвело до використання поряд 3 фінансовими $\mathrm{i}$ нефінансових (немонетарних) показників для аналізу. До немонетарних показників можна віднести прихильність споживачів до тієї чи іншої марки товару, якість продукції, обслуговування тощо.

Менеджерами-практиками всього світу наголошується на позитивній ролі і значенні таких невимірюваних, i в той же час дуже важливих чинників формування ринкової вартості, як інтелектуальний капітал, клієнтські відносини, бренди, імідж підприємства на ринку. Породження нових об'єктів викликає необхідність створення системи, яка допомогла б ïx оцінювати, ефективно використовувати i контролювати, оскільки фінансові показники не можуть відобразити стан цих активів або їх внесок в створення вартості.

У сучасних умовах вченими даної проблематики виділяються наступні підходи до комплексного управління підприємством:

$\begin{array}{ccc}\text { - } & \text { система збалансованих } & \text { показників } \\ \text { (Balanced } & \text { Scorecard } \quad- & \text { BSC) }\end{array}$


Р.С. Капланом і Д.П. Нортоном для досягнення стратегічної мети господарювання шляхом акцентування уваги на блоках показників (фінанси, навчання та перспективи зростання, клієнти, внутрішньогосподарські процеси та ін.) як фінансових так і немонетарних [2];

система показників відповідальності (Accountability Scorecard - ASC, Р. Фрімен, Ф. Ніколс), яка базується на виділенні груп зацікавлених осіб (власники, працівники, менеджери, постачальники та ін.) 3 метою узгодження їх інтересів через багатовекторність в управлінні та досягнення на підставі цього максимально можливого результату господарювання;

піраміда результативності (Performance pyramid, С.Дж. МакНейр, Р.Л. Лінч, К.Ф. Кросс), яка базується на організації виробництва 3 дотримання підходу до управління якістю та відповідної організації обліку (за функціональними сегментами) на підприємстві; система управління зв'язками із замовниками (CRM) передбачає необхідність відслідковування зв'язків 3 клієнтами та можливості встановлення рейтингу кожної з угод; модель ділової переваги (Business Excellence Model - BEM), розробникми якої $\epsilon$ Європейська фундація управління якістю (European Foundation of Quality Management) інструмент аналізу та контролю, який характеризується тісною інтеграцією 3 підходом до управління на основі якості.

Останнім часом активного розвитку набула система, що забезпечує планомірне виконання стратегічних цілей на рівні оперативної діяльності кожного працівника. Оскільки досягнення адекватно поставленої стратегічної цілі є неможливим без чіткої іiі деталізації, та формування результативних показників, щоб оцінювати роботу кожного відділу та працівника зокрема.

Дана система було розроблена проф. Р.С. Капланом та Д.П. Нортоном, та отримала назву Система збалансованих показників (Balanced Scorecard). Як зазначає дослідник Е. Шевченко, показники мають грунтуватися на місії та стратегії розвитку підприємства. Самим популярним інструментом на даному етапі виступає система Balanced Scorecard. Вона дозволяє на верхніх рівнях представити розроблену структуру стратегічних цілей $з$ показниками та шляхами їх досягнення, сприяє їх досягненню та у кінцевому етапі довести до співробітників [6].

Варто відмітити, що на практиці виконання стратегічних планів підприємства $€$ доволі складним завданням для його управлінців. Всі дії працівників суб'єкта господарювання мають бути скоординовані таким чином, щоб реалізувати цілі, 3 найменшими витратами та у максимально короткі строки.

Основними недоліками загального підходу до виміру ефективності господарювання на сучасному етапі $\epsilon$ наступні: використовуються лише кількісні показники, що не дає можливості об'єктивної оцінки ефективності; немонетарні показники розглядаються як другорядні; аналіз здійснюється лише окремих напрямів діяльності.

У свою чергу, зазначимо, що Система збалансованих показників направлена на усунення зазначених проблемних питань. Вона використовується як основний інструмент управління бізнесом, оскільки надає можливість встановлювати індивідуальні завдання, завдання структурних підрозділів та загальні завдання підприємства, доводити їх до свідомості співробітників і керівників різного рівня, оцінювати досягнення поставлених завдань за допомогою використання збалансованої системи вимірників ефективності, одержувати швидкий зворотний зв'язок.

Система збалансованих показників, не відкидаючи доцільності традиційних фінансових показників, використовує їх разом з показниками нефінансового характеру, що допомагає більш адекватно оцінювати ефективність діяльності суб'єкта господарювання, в т.ч. в контексті управління персоналом та виплатам йому.

BSC 3'явилась як результат дослідження різноманітних методів оцінки ефективності діяльності: рентабельність інвестицій, чистий прибуток на одну акцію, співвідношення ринкової та балансової вартості акцій, рентабельність акціонерного капіталу, рентабельність чистих активів, рентабельність грошового потоку, економічна додана вартість, прибуток до виплати процентів, податків та дивідендів, ринкова додана вартість, сукупна акціонерна доходність, грошовий потік віддачі на інвестований капітал.

На їх основі Р.С. Капланом і Д.П. Нортоном і була розроблена принципово інша система контролю ефективності та виконання стратегічних цілей, яка побудована на принципах: причиннонаслідковий зв'язок усіх показників; зв'язок результативних показників, які підприємство має можливість виміряти по закінченню певного періоду і показників, які можна виміряти миттєво; зв'язок усіх показників з фінансовими результатами діяльності.

Основною причиною розробки системи збалансованих показників слід вважати те, що 
існуючі традиційні системи оцінки результатів діяльності - 3 їх виключною залежністю від фінансових показників - втратили свою ефективність в умовах сучасного ділового світу, що характеризується створенням цінності на базі таких нематеріальних активів, як знання та досвід працівників, тісні зв'язки 3 клієнтами, культура новаторства i проведення реформ. Тобто основною особливістю даної системи $\epsilon$ використання взаємопов'язаного набору фінансових та нефінансових показників, оскільки автори концепції виявили, що лише фінансових показників недостатньо для адекватної оцінки діяльності підприємства.

BSC призначена дати відповідь на чотири найважливіших питання, які, у свою чергу, виступають іï складовими:

1) аспект клієнта (як підприємство оцінюють клієнти);

2) внутрішньогосподарський аспект (які процеси можуть забезпечити підприємству виняткові конкурентні переваги);

3) аспект інновацій і навчання (яким чином можна досягти подальшого поліпшення стану підприємства);

4) фінансовий аспект (як оцінюють підприємство акціонери).

Працівники підприємства відіграють важливу роль у його функціонуванні. Від їх кваліфікації та вмінь залежить результат поставлених завдань та цілей. Отже, розглянемо детальніше проекцію «Навчання та розвиток». Даний блок, як і всі інші, складається 3 цілей, показників, завдань та заходів. Цілі відображають бажаний стан, якого прагне досягнути підприємство. Показники конкретизують поставлені цілі. Завдання показують, якими хоче бачити керівництво наведені показники. Наприклад, доступність інформаційних систем має становити $100 \%$. Заходи відображають дії, які має здійснити підприємство для досягнення завдань та цілей.

Взагалі, впровадження будь-якої стратегії починається 3 навчання тих, хто має їі реалізовувати. За допомогою спеціально розроблених програм навчання, періодичних зборів, корпоративних послань та інформаційних систем керівництво здійснює функцію комунікації стратегічного бачення. Даний процес дає йому змогу реалізовувати стратегію у різних напрямах, забезпечуючи тим самим зв'язок загальних цілей 3 цілями структурних підрозділів i функціями окремих співробітників.

3 позиції Л.В. Пана менеджери середнього рівня залучаються у процес розробки стратегій в галузі навчання і розвитку, а також внутрішніх бізнес-процесів, визначаючи ключові процеси, потенціал співробітників і вимоги до використовуваних технологій. Крім того, ім делегується розробка інфраструктури моделі на нижчих рівнях ієрархії. Зокрема, розробляються вимірники ефективності роботи відділів та індивідуальних показників, що оцінюють ефективність роботи кожного співробітника [4]. Відповідно, формування мотиваційної системи на основі збалансованої системи показників забезпечує залучення кожного працівника у процес підвищення ефективності діяльності суб'єкта господарювання.

Одним із складових акценту інновацій та навчання Системи збалансованих показників має бути формування достатнього рівня освіти працівників підприємства, що забезпечував би необхідний розвиток та досягнення стратегічних цілей суб'єкта господарювання. Тому, 3 нашої позиції, при визначені основних цілей та напрямів розвитку в даному блоці Системи збалансованих показників необхідно брати до уваги й дану складову трудового потенціалу, та формувати бажаний рівень іiі розвитку.

Культура підприємства формує його репутацію на ринку функціонування, визначає рівень оцінки його покупцями та постачальниками. Досягнення встановленого рівня репутації визначається у складовій Клієнти Системи збалансованих показників підприємства. Отже, процес формування загальної корпоративної культури підприємства можна включити саме до даної складової.

При навчанні персоналу особливо суттєвий взаємозв'язок між різними показниками діяльності підприємства. Якщо суб'єкт господарювання прагне стати прибутковим, він повинен досягати лояльності зі сторони споживачів. Для того, щоб споживачі зберігали лояльність до нього, необхідно покращити якість ïx обслуговування. Щоб досягнути покращення якості обслуговування, необхідно здійснювати операції по всьому ланцюжку цінностей організації, а для цього потрібний розвиток знань, навиків та здібностей робітників [1]. Сукупністю вмінь, навиків, здібностей людини, які використовуються в економічній діяльності та значно впливають на зростання продуктивності праці та економічної доданої вартості, називається людський капітал підприємства.

Відповідно, в ході дослідження порядку використання збалансованої системи показників сформовано методику аналітичного забезпечення відтворення людського капіталу в контексті використання BSC. Дана методика передбачає ряд послідовних дій (рис. 1). 
На першому етапі підприємство повинно поставити стратегічну ціль, наприклад збільшення прибутковості. На другому етапі підприємство

повинно зосередити свою увагу лише на тих напрямах діяльності, які дійсно відповідають досягненню поставленої цілі. Третій етап передбачає визначення завдань, наприклад, зменшення плинності кадрів, підвищення кваліфікації персоналу; четвертий визначає як кожне із завдань, при його виконанні, вплине на досягнення цілі підприємства. На п'ятому слід обрати певні фінансові показники, що характеризують поставлене завдання. Наприклад, завдання щодо зниження плинності кадрів можна вирішити, проаналізувавши коефіцієнти плинності, постійності, вибуття та приймання. Шостий призначений для розробки певного плану дій, який допоможе вирішити поставлені завдання, на основі наведених фінансових показників. На сьомому необхідно обрати відповідальних за кожен етап виконання завдання, а на восьмому відбувається саме впровадження проекту. Останній етап передбачає можливе як повернення на етап формування показників ефективності, так і на перший етап формування стратегічної цілі.

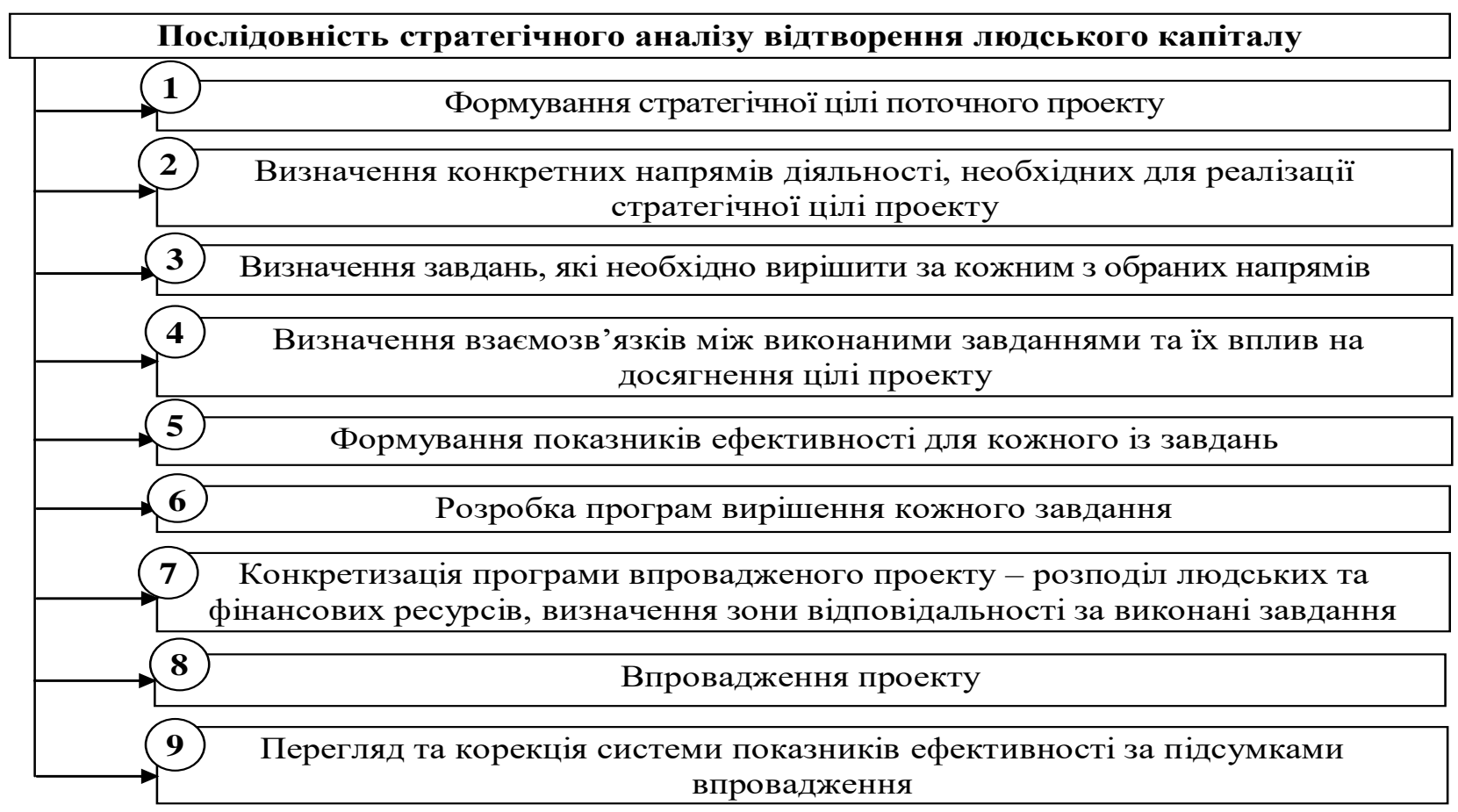

Рис. 1. Методика аналітичного забезпечення відтворення людського капіталу в системі стратегічного вимірювання бізнесу*

*Джерело: побудовано автором на основі [2; 5]

У відповідності до системи збалансованих показників перелік стратегічних завдань суб'єкта господарювання слід відображати у вигляді стратегічних

карт [3]. Модель стратегічних карт дозволяє одночасно контролювати реалізацію цілей у всіх чотирьох аспектах; іiї перевага в тому, що вона дозволяє визначити основні направлення для досягнення успіху діяльності. $\mathrm{y}$ даному контексті, модель стратегічних карт - це процес нерозривної послідовності дій.

Місія підприємства отримує наочне втілення і може бути доведена до відома всіх працівників. Вона представлена у вигляді конкретних цілей та стимулів для їх досягнення. Це необхідно для зосередження зусиль на найбільш важливих направленнях розподілу ресурсів та встановлення цілей. $\mathrm{У}$ результаті працівники навчаються стратегічно мислити і можуть доносити власні ідеї і доповнення у формулювання місії та стратегії підприємства, що в свою чергу, веде до його переосмислення на новому рівні. На кожному етапі свого використання стратегічні карти $€$ засобом широкого поширення місії та стратегії підприємства.

Використовуючи стратегічну карту управлінці отримують відповіді на основні запитання: що необхідно зробити для вирішення стратегічних завдань, за рахунок чого компанія створює свою вартість. У результаті використання карти при створенні збалансованої системи показників діяльність компанії стає більш зрозумілою та 
структурованою.

Правильно складена стратегічна карта повинна містити інформацію про минулу та майбутню стратегію конкретного суб'єкта господарювання. Показники, які включені в стратегічну карту повинні характеризувати як досягнуті результати, так i основні фактори, які обумовили їx. Розроблена стратегічна карта (табл. 1) враховує вплив трудових ресурсів на кінцевий результат діяльності підприємства. Отже, для побудови стратегічної карти ми поставили ціль та визначили головні завдання в межах кожної проекції.

Необхідною складовою стратегічної карти є перспектива «Навчання та розвиток». Виникнення витрат на підвищення кваліфікації персоналу підприємства, а саме витрат на семінари, тренінги $є$ необхідним 3 точки зору забезпечення інтелектуального розвитку кадрів та можливості використання навиків та вмінь для стратегічного розвитку підприємства. Крім того, підприємство має аналізувати задоволеність та мотивацію працівників, а саме їх підвищення.

Розроблена стратегічна карта сприяє якісній оцінці впливу трудового потенціалу на збільшення ефективності господарської діяльності підприємства, що в подальшому

Таблиця 1

Запропонована стратегічна карта за основною ціллю - підвищення кваліфікації працівників задля дотримання стратегії розвитку економічного суб' скта* *

\begin{tabular}{|c|c|c|c|c|c|}
\hline \multirow[b]{2}{*}{$\begin{array}{l}\text { Перспекти } \\
\text { ва }\end{array}$} & \multirow[b]{2}{*}{ Цільова установка } & \multicolumn{3}{|c|}{ Показники досягнення цілей } & \multirow{2}{*}{$\begin{array}{c}\text { Заходи, } \\
\text { спрямовані на } \\
\text { досягнення } \\
\text { цілей }\end{array}$} \\
\hline & & Найменування, & $\begin{array}{l}\text { Од. } \\
\text { виміру }\end{array}$ & $\begin{array}{c}\text { Цільове } \\
\text { значен ня } \\
\text { / дата* }\end{array}$ & \\
\hline 2 & 3 & 4 & 5 & 6 & 8 \\
\hline \multirow{14}{*}{ Фінанси } & \multirow{6}{*}{$\begin{array}{c}\text { 1. Оптимізація } \\
\text { величини витрат } \\
\text { на продукцію, в } \\
\text { т.ч. шляхом } \\
\text { підвищення } \\
\text { ефективності } \\
\text { використання } \\
\text { трудових ресурсів }\end{array}$} & $\begin{array}{l}\text { Витрати на запаси (\% від } \\
\text { загальних витрат) }\end{array}$ & $\%$ & & \multirow{14}{*}{$\begin{array}{c}\text { Знаходження } \\
\text { вигідних } \\
\text { постачальників } \\
\text { сировини та } \\
\text { матеріалів; } \\
\text { придбання } \\
\text { матеріалів у } \\
\text { зарубіжних } \\
\text { постачальників } \\
\text { за низькими } \\
\text { цінами }\end{array}$} \\
\hline & & $\begin{array}{l}\text { Витрати на маркетингові } \\
\text { дослідження }\end{array}$ & грн. & & \\
\hline & & Витрати на рекламу & грн. & & \\
\hline & & Матеріаловіддача & - & & \\
\hline & & Віддача основних засобів & - & & \\
\hline & & Фондоозброєність & $\begin{array}{l}\text { тис.грн/чо } \\
\text { л. }\end{array}$ & & \\
\hline & \multirow{2}{*}{$\begin{array}{l}\text { 2. Збільшення } \\
\text { кількості клієнтів }\end{array}$} & Кількість клієнтів & чол. & & \\
\hline & & Кількість залучених клієнтів & чол. & & \\
\hline & \multirow{6}{*}{$\begin{array}{l}\text { 3. Підвищення } \\
\text { ресурсних, } \\
\text { доходних і } \\
\text { витратних } \\
\text { показників } \\
\text { рентабельності }\end{array}$} & Прибуток & тис. грн. & & \\
\hline & & Рентабельність продукції & $\%$ & & \\
\hline & & Рентабельність виробництва & $\%$ & & \\
\hline & & Рентабельність продажу & $\%$ & & \\
\hline & & Рентабельність підприємства & $\%$ & & \\
\hline & & $\begin{array}{l}\text { Рентабельність власного } \\
\text { капіталу }\end{array}$ & $\%$ & & \\
\hline \multirow{7}{*}{ Кліснти } & \multirow{4}{*}{$\begin{array}{c}\text { 1. Формування } \\
\text { бази постійних } \\
\text { контрагентів } \\
\text { (клієнтів) }\end{array}$} & $\begin{array}{l}\text { Кількість клієнтів, які } \\
\text { звернулися повторно }\end{array}$ & чол. & & \multirow{7}{*}{$\begin{array}{c}\text { Розробка нової } \\
\text { системи } \\
\text { вивчення } \\
\text { задоволеності } \\
\text { клієнтів; } \\
\text { формування } \\
\text { мережі } \\
\text { представників } \\
\text { за регіонами } \\
\text { країни }\end{array}$} \\
\hline & & $\begin{array}{lc}\text { Відсоток } & \text { клієнтів, } \\
\text { звернулися повторно }\end{array}$ & $\%$ & & \\
\hline & & Рівень цін & $\%$ & & \\
\hline & & Обсяг продажу & тис. грн. & & \\
\hline & \multirow{3}{*}{$\begin{array}{c}\text { 2. Розробка за } \\
\text { ходів із пошуку } \\
\text { нових клієнтів, } \\
\text { переведення їх в } \\
\text { статус постійних, } \\
\text { підвищення їх } \\
\text { задоволеності }\end{array}$} & $\begin{array}{l}\text { Витрати на залучення одного } \\
\text { клієнта }\end{array}$ & грн. & & \\
\hline & & Кількість залучених клієнтів & чол. & & \\
\hline & & $\begin{array}{l}\text { Відсоток незадоволених } \\
\text { клієнтів }\end{array}$ & $\%$ & & \\
\hline
\end{tabular}


Продовження таблиці 1

\begin{tabular}{|c|c|c|c|c|c|}
\hline \multirow[b]{2}{*}{$\begin{array}{l}\text { Перспекти } \\
\text { ва }\end{array}$} & \multirow[b]{2}{*}{ Цільова установка } & \multicolumn{3}{|c|}{ Показники досягнення цілей } & \multirow{2}{*}{$\begin{array}{c}\text { Заходи, } \\
\text { спрямовані на } \\
\text { досягнення } \\
\text { цілей }\end{array}$} \\
\hline & & Найменування, & $\begin{array}{c}\text { Од. } \\
\text { виміру }\end{array}$ & $\begin{array}{l}\text { Цільове } \\
\text { значен ня } \\
\text { / дата* }\end{array}$ & \\
\hline 2 & 3 & 4 & 5 & 6 & 8 \\
\hline \multirow{14}{*}{$\begin{array}{l}\text { Внутрішн } \\
\text { i бізнес- } \\
\text { процеси }\end{array}$} & \multirow{4}{*}{$\begin{array}{c}\text { 1. Виробіток } \\
\text { продукції, що } \\
\text { відповідає вну } \\
\text { трішнім та галу } \\
\text { зевим стандар там } \\
\text { якості }\end{array}$} & Обсяг реалізації & тис. грн. & & \multirow{14}{*}{$\begin{array}{c}\text { Впровадження } \\
\text { плану } \\
\text { коригуючих } \\
\text { заходів щодо } \\
\text { закупівлі ТМЦ; } \\
\text { розробка } \\
\text { програми } \\
\text { навчання } \\
\text { співробітників } \\
\text { та нової } \\
\text { системи } \\
\text { планування } \\
\text { проектів }\end{array}$} \\
\hline & & $\begin{array}{l}\text { Собівартість одиниці } \\
\text { продукції }\end{array}$ & грн. & & \\
\hline & & Рентабельність продукції & $\%$ & & \\
\hline & & Продуктивність праці & $\begin{array}{l}\text { тис. грн. } \\
\text { /чол. }\end{array}$ & & \\
\hline & \multirow{6}{*}{$\begin{array}{c}\text { 2. Дотримання } \\
\text { графіку поставки } \\
\text { продукції }\end{array}$} & Витрати на поставку & грн. & & \\
\hline & & $\begin{array}{l}\text { Період обертання оборотних } \\
\text { активів }\end{array}$ & дні & & \\
\hline & & Коефіцієнт покриття & - & & \\
\hline & & Коефіцієнт оборотності & - & & \\
\hline & & $\begin{array}{l}\text { Відсоток своєчасно } \\
\text { замовлених ТМЦ }\end{array}$ & $\%$ & & \\
\hline & & $\begin{array}{l}\text { Відсоток виконання строків } \\
\text { складання плану закупівлі }\end{array}$ & $\%$ & & \\
\hline & \multirow{4}{*}{$\begin{array}{c}\text { 3. Налагоджен ня } \\
\text { постачальни цько- } \\
\text { заготівель ної } \\
\text { діяльності запасів } \\
\text { у перевірених } \\
\text { постачальників }\end{array}$} & Рівень браку & $\%$ & & \\
\hline & & $\begin{array}{l}\text { Витрати на одиницю } \\
\text { матеріалів }\end{array}$ & грн. & & \\
\hline & & Норми витрачання матеріалів & $\mathrm{T}$ & & \\
\hline & & $\begin{array}{l}\text { Відсоток порушень строків } \\
\text { поставки ТМЦ }\end{array}$ & $\%$ & & \\
\hline \multirow{12}{*}{$\begin{array}{l}\text { Навчання } \\
\text { та розви- } \\
\text { ток }\end{array}$} & \multirow{4}{*}{$\begin{array}{l}\text { 1. Організація } \\
\text { підвищення } \\
\text { кваліфікації } \\
\text { працівників }\end{array}$} & $\begin{array}{l}\text { Витрати на підвищення } \\
\text { кваліфікації }\end{array}$ & грн. & & \multirow{12}{*}{$\begin{array}{c}\text { Участь } \\
\text { працівників } \\
\text { підприємства у } \\
\text { семінарах, } \\
\text { тренінгах; } \\
\text { розробка } \\
\text { програм } \\
\text { навчання } \\
\text { персоналу }\end{array}$} \\
\hline & & $\begin{array}{ll}\text { Відсоток } & \text { кваліфікованих } \\
\text { працівників } & \\
\end{array}$ & $\%$ & & \\
\hline & & $\begin{array}{lll}\begin{array}{l}\text { Витрати } \\
\text { персоналу }\end{array} & \text { на } & \text { навчання }\end{array}$ & грн. & & \\
\hline & & $\begin{array}{lcl}\text { Кількість } & \text { програм } \\
\text { підвищення кваліфікації }\end{array}$ & шт. & & \\
\hline & \multirow{8}{*}{$\begin{array}{l}\text { 2. Удосконалення } \\
\text { мотивацій ної } \\
\text { системи на } \\
\text { підприємстві з } \\
\text { метою знижен ня } \\
\text { процесу плинності } \\
\text { працівників }\end{array}$} & Продуктивність праці & $\begin{array}{l}\text { тис.грн./ч } \\
\text { ол. }\end{array}$ & & \\
\hline & & Премії & грн. & & \\
\hline & & Надбавки та доплати & грн. & & \\
\hline & & Фонд оплати праці & грн. & & \\
\hline & & Коефіцієнт прийому & - & & \\
\hline & & Коефіцієнт плинності & - & & \\
\hline & & Коефіцієнт вибуття & - & & \\
\hline & & Коефіцієнт постійності & - & & \\
\hline
\end{tabular}

* Цільове значення та изільова дата заповнюються у разі наявності джерел даної інформаиії

**Джерело: розроблено автором на основі [2]

забезпечить вихід на світовий ринок, зростання конкурентоспроможності підприємства на ньому, задоволеність покупців та працівників підприємства

Висновки та перспективи подальших досліджень. Розглянувши позицію розробників Д. Нортона та Р. Каплана збалансованої системи показників визначили, що розгляд чотирьох напрямів оцінки ефективності діяльності підприємства (фінанси, клієнти, внутрішні бізнеспроцеси, навчання та розвиток) дозволяє керівникам отримувати інформацію на основі індивідуально розроблених показників ефективності, порівняння планових і фактичних 
даних, робити оцінку ефективності реалізації стратегії.

Однією 3 важливих проекцій збалансованої системи показників є проекція «Навчання та розвиток», адже без працівників, їх кваліфікації, умінь підприємство не зможе досягти поставлених стратегічних цілей. $\mathrm{y}$ даному блоці слід зосередитися на розгляді таких цілей як підвищення задоволеності та мотивації працівників, зменшення плинності кадрів, підвищення кваліфікації працівників, ефективності роботи інформаційних систем тощо, що підтверджує важливу роль людського капіталу в досягненні стратегії підприємства.

Результати проведеного дослідження можуть бути покладені в основу подальших досліджень практичного застосування системи збалансованих показників підприємствами різних галузей економіки з виділенням специфіки діяльності.

\section{ПЕРЕЛІК ВИКОРИСТАНИХ ДЖЕРЕЛ.}

1. Аронова Л. Balanced Scorecard - мировые стандарты и российский опыт [Електронний ресурс] / Л. Аронова // Intellegent Enterprise. - 2003. - № 5. - Режим доступу до журн.: http://www.balancedscorecard.ru/bsc698.htm

2. Каплан Р. Сбалансированная система показателей. От стратеги к действию / [Р. Каплан, Д. Нортон; пер. с анг.]. - 2-е изд., испр. и доп. - М.: Олимп-Бизнес, 2004. - 320с.

3. Нивен Пол Р. Діагностика збалансованої системи показників: Підтримуючи максимальну ефективність / Нивен Пол Р. ; [пер. з англ.; за наук. ред. М. Горського]. - Дніпропетровськ: Баланс Бізнес Букс, 2006. - 256 с.

4. Пан Л.В. Збалансована система показників як інструмент ефективного управління стратегією організації [Електронний ресурс] / Л.В. Пан. - Режим доступу: http://www.library.ukma.kiev.ua/elib/NZ/NZV21_2003_economy/09_pan_lv.pdf.

5. Потриваєва Н.В. Система збалансованих показників як аналітичний засіб підвищення ефективності функціонування підприємств [Електронний ресурс] / Н.В. Потриваєва // Ефективна економіка. - 2015 - №12. - Режим доступу до ресурсу: http://www.economy.nayka.com.ua/?op=1\&z=5092

6. Шевченко Е. Контролинг, или Кто владеет информацией - владеет миром / Е. Шевченко // Справочник экономиста - № 3 - 2008. - С. 64-67.

\section{REFERENCES}

1. Aronova, L. (2003). Balanced Scorecard - mirovye standarty i rossijskij opyt [Balanced Scorecard world standards and the Russian experience]. Intellegent Enterprise - Intellegent Enterprise, 5. balancedscorecard.ru. Retrieved from: http://www.balancedscorecard.ru/bsc698.htm [in Russian].

2. Kaplan, R. (2004). Sbalansyrovannaya systema pokazateley. Ot stratehy k deystvyyu [A balanced scorecard. From strategy to action.]. M.: Olymp-Byznes [in Russian].

3. Nyven, Pol R. (2006). Diahnostyka zbalansovanoyi systemy pokaznykiv: Pidtrymuyuchy maksymal'nu efektyvnist [Diagnosis of a balanced scorecard: Maintaining maximum efficiency]. Dnipropetrovsk: Balans Biznes Buks [in Ukrainian].

4. Pan, L.V. (n.d.). Zbalansovana systema pokaznykiv yak instrument efektyvnoho upravlinnya stratehiyeyu orhanizatsiyi [Balanced Scorecard as an instrument for effective strategy management of an organization]. library.ukma.kiev.ua. Retrieved from: http://www.library.ukma.kiev.ua/elib/NZ/NZV21_2003_economy/09_pan_lv.pdf [in Ukrainian].

5. Potryvayeva, N.V. (2015). Systema zbalansovanykh pokaznykiv yak analitychnyy zasib pidvyshchennya efektyvnosti funktsionuvannya pidpryyemstv [Balanced Scorecard system as an analytical means of improving the efficiency of enterprises]. Efektyvna ekonomika - Effective Economics, 12. economy.nayka.com.ua. Retrieved from: http://www.economy.nayka.com.ua/?op=1\&z=5092 [in Ukrainian].

6. Shevchenko, E. (2008). Kontrolinh, ili Kto vladeet informatsyey - vladeet myrom [Controlling, or Who owns the information - owns the world]. Spravochnyk ekonomista - Economist's Handbook, 3, 64-67 [in Ukrainian]. 